\title{
Characterization of DRA0282 from Deinococcus radiodurans for its role in bacterial resistance to DNA damage
}

Correspondence

Hari S. Misra

hsmisra@barc.gov.in

Received 12 April 2010

Revised 20 January 2011

Accepted 18 April 2011

\author{
Anubrata D. Das and Hari S. Misra \\ Molecular Biology Division, Bhabha Atomic Research Centre, Mumbai 400 085, India
}

\section{INTRODUCTION}

Deinococcus radiodurans $\mathrm{R} 1$ shows extraordinary tolerance to several abiotic stresses, including ionizing and nonionizing radiation (Makarova et al., 2001; Cox \& Battista 2005; Blasius et al., 2008). This bacterium possesses an efficient DNA double-strand break (DSB) repair mechanism (Minton, 1994; Daly \& Minton, 1996) and strong oxidative stress tolerance mechanisms (Markillie et al., 1999; Daly et al., 2004, 2007). DSB repair in this organism displays RecA-dependent biphasic kinetics (Daly et al., 1994; Slade et al., 2009). Phase I involves extended synthesis-dependent strand annealing (ESDSA) processes (Zahradka et al., 2006), followed by the second phase of the maturation of individual chromosomes, which presumably involves homologous recombination (Daly \& Minton, 1996). The $D$. radiodurans R1 genome (White et al., 1999) shows the absence of $\operatorname{rec} B C$ and $s b c B / s b c A$ genes, while the recD2 protein (Montague et al., 2009) and components of the complete RecF pathway are present (Blasius et al., 2008). Expression of $s b c B$ (Misra et al., 2006) and recBC (Khairnar et al., 2008) genes of Escherichia coli in

Abbreviations: DSB, double-strand break; Exolll, exonuclease III; FTICRMS, Fourier transform ion cyclotron resonance-MS; PIR, post-irradiation recovery.

Five supplementary figures and two supplementary tables are available with the online version of this paper.
D. radiodurans makes this bacterium sensitive to gamma radiation by delaying its DSB repair, further supporting the contention that the RecF recombination pathway contributes to DSB repair and radiation resistance in this bacterium. The role of the RecFOR pathway in DSB repair through an ESDSA mechanism has been suggested in $D$. radiodurans (Bentchikou et al., 2010). However, the significance of DNA protection in radiation resistance and DSB repair during the early phase of post-irradiation recovery (PIR) has also been shown. Two proteins, namely DdrA (Harris et al., 2004) and PprA (Narumi et al., 2004), have been characterized for their roles in DNA protection and radiation resistance in D. radiodurans. Also, recently, the involvement of reversible protein phosphorylation in the regulation of nucleolytic degradation during PIR has been suggested (Kamble et al., 2010).

Here, we report the characterization of DRA0282 from $D$. radiodurans for its role in DNA protection from exonuclease degradation in vitro and in radiation resistance in vivo. The recombinant protein showed stronger binding to superhelical DNA and protected dsDNA from exonuclease III (ExoIII) degradation in vitro. The DR_A0282 deletion mutant $(\Delta d r A 0282)$ of $D$. radiodurans showed a dosedependent effect, and these cells displayed nearly 10 -fold less resistance as compared with the wild-type at a $14 \mathrm{kGy}$ dose of gamma radiation. Deletion of $d r A 0282$ in a $p$ prAminus background (pprA::cat $\Delta d r A 0282)$, however, 
showed no additive effect to the pprA mutant phenotype, although a double mutant showed nearly a 10 -fold higher sensitivity than the $\triangle d r A 0282$ mutant. E. coli cells expressing DRA0282 showed a RecA-dependent enhancement of UV $(254 \mathrm{~nm})$ and gamma radiation resistance. Although SOS-deficient but recombination-proficient $E$. coli cells expressing DRA0282 showed an increase in DNA damage tolerance, the increase was significantly less than that of wild-type cells expressing the same protein. This indicated that both recombination and SOS mechanisms are important for DRA0282 function in vivo. Thus, we characterized DRA0282 as a DNA-binding protein with a preference for superhelical DNA, and demonstrated that it contributes to bacterial resistance to DNA damage by mechanism(s) that require RecA, at least in E. coli.

\section{METHODS}

Bacterial strains and materials. D. radiodurans ATCC13929 was a generous gift from Dr M. Schäfer, Germany (Schäfer et al., 2000). The wild-type and its derivatives were grown aerobically in TGY $(0.5 \%$ Bacto tryptone, $0.3 \%$ Bacto yeast extract, $0.1 \%$ glucose) with or without kanamycin $\left(8 \mu \mathrm{g} \mathrm{ml}^{-1}\right)$. TGY agar plates were incubated at $32{ }^{\circ} \mathrm{C}$ for $48 \mathrm{~h}$ and colonies were counted. E. coli and its derivatives were grown in Luria-Bertani (LB) medium supplemented with appropriate antibiotics. Other recombinant techniques were as described in Sambrook \& Russell (2001). Molecular biology grade chemicals were purchased from Sigma, Roche Biochemicals, New England Biolabs and Bangalore Genei.

DNA-binding protein fractionation. Exponentially growing cells were irradiated with $6 \mathrm{kGy}$ of gamma radiation. Aliquots were collected at $1 \mathrm{~h}$ intervals and cell-free extract was prepared in lysis buffer $\left(20 \mathrm{mM}\right.$ Tris/HCl, pH 7.6, $1 \mathrm{mM} \mathrm{MgCl}_{2}, 1 \mathrm{mM}$ DTT, $1 \mathrm{mM}$ PMSF, $200 \mu \mathrm{g}$ lysozyme $\mathrm{ml}^{-1}$ ), as described previously (Kota \& Misra, 2008). Soluble proteins were diluted with 10 volumes of buffer A $(10 \mathrm{mM}$ sodium phosphate, $\mathrm{pH} 7.0,50 \mathrm{mM} \mathrm{NaCl}, 1 \mathrm{mM}$ EDTA, $\mathrm{pH} 8.0,1 \mathrm{mM}$ DTT, $1 \mathrm{mM}$ PMSF) and passed through a heparinSepharose affinity column as described previously (Kamble et al., 2010). Proteins were eluted with $500 \mathrm{mM} \mathrm{NaCl}$ in buffer A. The protein concentration was determined, and the heparin-purified fraction showing ATP inhibition of nucleolytic function was treated with alkaline phosphatase and refractionated on a MonoQ column by FPLC. Proteins were eluted with a salt gradient $(50-500 \mathrm{mM} \mathrm{NaCl})$ in $50 \mathrm{mM}$ Tris/HCl buffer, $\mathrm{pH} 7.5$, containing $10 \%(\mathrm{v} / \mathrm{v})$ glycerol and $1 \mathrm{mM}$ DTT. Fractions were assayed for nuclease activity in the presence and absence of $2 \mathrm{mM}$ ATP. Fraction 12, which showed ATP inhibition of nucleolytic function, was analysed by Fourier transform ion cyclotron resonance-MS (FTICR-MS).

Functional domain analysis. Functional domain analysis of DRA0282 was carried out using standard online bioinformatics tools. In brief, a PSI-BLAST search was done with the Swiss-Prot database, with default parameters and the keyword 'DNA repair'. Initial iterations showed Ku80 and PRP19/PSO4 from yeast, and these were selected for further iterations. After five iterations, several Ku-like proteins were found. We selected these sequences, and multiple sequence alignment was carried out, including prokaryotic $\mathrm{Ku}$ proteins, in CLUSTAL_X. This procedure was repeated further to align DRA0282 with $\mathrm{Ku}$ proteins alone. DRA0282 again clustered with eukaryotic Ku. Next we built a neighbour-joining tree and bootstrapped it 1000 times. Secondary structure was inferred from PSIPRED, JNET and Professor at the Quick 2D server at the Max Planck Institute for Developmental Biology. For 3D structure determination, we initially submitted the protein sequence to online servers such as I-TASSER and PHYRE, and the templates with closest matches were obtained from these servers. We subsequently built a 3D model in SWISS-MODEL, in the alignment mode, using 1JEY, the human $\mathrm{Ku}$ heterodimer structure, as the template (Arnold et al., 2006), and residues 1-486 were modelled at minimum free energy stabilization.

Construction of a DR_A0282 expression plasmid and recombinant protein purification. Genomic DNA of $D$. radiodurans was prepared as described in Battista et al. (2001) and used for PCR amplification of $d r A 0282$ coding sequences using a gene-specific forward primer $282 \mathrm{~F}$ ( $5^{\prime}$-GAATTCATATGTTCATGAAGAGCAAGG$\left.3^{\prime}\right)$ and reverse primer 282R (5'-ACGGGATCCTAACTGACGGGAGGTGA-3'), which incorporated restriction enzyme sites at the $5^{\prime}$ ends of the primers. The $1.515 \mathrm{~kb}$ PCR product was ligated at NdeI and BamHI in pET28a + to yield pET282, and at $\mathrm{NcoI}$ and BamHI sites in $\mathrm{p} \operatorname{Trc} 99$ to yield $\mathrm{p} \operatorname{Trc} 282$. The $\mathrm{p} \operatorname{Trc} 282$ plasmid was used for studying the effect of DRA0282 expression on the radiation response of the wild-type (E. coli AB1157) and recA mutant (E. coli JC1553) of E. coli K-12 (Supplementary Table S1). The pET282 plasmid was transferred to E. coli BL21(DE3) pLysS, and cells were induced with $200 \mu \mathrm{M}$ IPTG for purification of recombinant DRA0282 using metal affinity chromatography, as described previously (Misra et al., 1998). DRA0282 purified under denaturing conditions was refolded by serial dilution of urea in buffer with an increasing concentration of DTT, as described previously (Khairnar \& Misra, 2009). The refolded protein was dialysed in $10 \mathrm{mM}$ Tris/ $\mathrm{HCl}, \mathrm{pH} 7.5,15 \mathrm{mM} \mathrm{KCl}, 1 \mathrm{mM}$ DTT and $50 \%(\mathrm{v} / \mathrm{v})$ glycerol, and stored at $-20{ }^{\circ} \mathrm{C}$ for further use.

Isolation of a deletion mutant of $\boldsymbol{D}$. radiodurans. The $d r A 0282$ deletion mutant was generated using protocols described previously (Khairnar et al., 2008). In brief, the $1 \mathrm{~kb}$ upstream and downstream fragments of the coding sequences of $d r A 0282$ were PCR-amplified using sequence-specific primers. The upstream fragment was amplified using primers $282 \mathrm{upF}$ ( $5^{\prime}$-ATGGGCCCGCTTTGTACTCCAGAGCA-3') and 282upR (5'-CGGAATTCTTCATGAACACCAGGT$\left.3^{\prime}\right)$, and the downstream fragment was amplified using $282 \mathrm{dnF}$ (5'-ATGGATCCACCACCCGTCAGTAAGCT-3') and 282dnR (5'-CGTCTAGAAGCGCCCTGGTTGACCGT- $3^{\prime}$ ). The products were cloned independently and sequentially in pNOKOUT (Khairnar et al., 2008) to yield pNOK282. This plasmid was linearized with ScaI and transformed into $D$. radiodurans to generate the $\Delta d r A 0282$ mutant. PCR amplification was carried out using sequence-specific primers, and complete replacement of $d r A 0282$ with the nptII gene was confirmed. These clones were considered as $\Delta d r A 0282$ mutants, and a single such clone was used for further studies.

To generate the double mutant of pprA and $d r A 0282$, linearized pNOK282 was transformed into the pprA::cat mutant of $D$. radiodurans (Narumi et al., 2004). Recombinant cells were subcultured for many generations in TGY broth containing both chloramphenicol $\left(5 \mu \mathrm{g} \mathrm{ml}{ }^{-1}\right)$ and kanamycin $\left(10 \mu \mathrm{g} \mathrm{ml} \mathrm{ml}^{-1}\right)$. Genomic DNA was prepared, and the absence of $d r A 0282$ in the pprA mutant background was ascertained by PCR amplification using gene-specific primers.

Cell survival studies. Cell survival studies were carried out as described previously (Rajpurohit et al., 2008). In brief, mutant and wild-type $D$. radiodurans cells were grown in TGY broth to the lateexponential phase at $32{ }^{\circ} \mathrm{C}$. Cells were suspended in sterile PBS and exposed to various doses of gamma radiation at a dose rate of $5.89 \mathrm{kGy} \mathrm{h}^{-1}$ (Gamma 5000, ${ }^{60} \mathrm{Co}$, Board of Radiation and Isotopes Technology, Department of Atomic Energy, India). Appropriate dilutions were plated on TGY agar plates and incubated at $32{ }^{\circ} \mathrm{C}$. E. coli cells expressing DRA0282 on pET282 and pTrc282 were treated with different doses of UV $(254 \mathrm{~nm})$ and gamma radiation as 
described previously (Kota \& Misra, 2006). In brief, exponentially growing E. coli cells induced with $200 \mu \mathrm{M}$ IPTG were washed with and resuspended in PBS, and treated with various doses of gamma radiation at a dose rate of $356 \mathrm{~Gy} \mathrm{~h}^{-1}$ (Gammacell 220 irradiator, MDS Nordion) and UV at $254 \mathrm{~nm}$. UV-treated cells were plated on LB agar plates containing kanamycin $\left(25 \mu \mathrm{g} \mathrm{ml}^{-1}\right)$ and incubated in the dark. The plates were incubated at $37^{\circ} \mathrm{C}$ overnight for E. coli and for $36 \mathrm{~h}$ at $32{ }^{\circ} \mathrm{C}$ for $D$. radiodurans before c.f.u. were counted.

DNA binding and Exolll protection studies. The DNA-binding assay was carried out as described previously (Kamble et al., 2010). In brief, $100 \mathrm{ng}$ purified DRA0282 and $500 \mathrm{ng}$ heparin-purified proteins were incubated with $200 \mathrm{ng}$ PCR-amplified deinococcal DNA/superhelical form of pBluescript SK +/single-stranded linear DNA in buffer containing $10 \mathrm{mM}$ Tris/ $\mathrm{HCl}, \mathrm{pH} 7.5,5 \mathrm{mM} \mathrm{MnCl}_{2}, 15 \mathrm{mM} \mathrm{KCl}$ and $2 \%(\mathrm{v} / \mathrm{v})$ glycerol for $20 \mathrm{~min}$ at $37^{\circ} \mathrm{C}$. To determine the effect of ATP, the proteins were pre-incubated with $2 \mathrm{mM}$ ATP for $20 \mathrm{~min}$ at $37^{\circ} \mathrm{C}$, followed by incubation with $200 \mathrm{ng}$ DNA substrate for $30 \mathrm{~min}$. The ExoIII protection assay was performed as described elsewhere (Wang et al., 2005). In brief, 200 ng DNA substrate was pre-incubated with different concentrations of purified DRA0282 for $10 \mathrm{~min}$ in Exonuclease III Buffer (New England Biolabs). The reaction mixture was further incubated for $20 \mathrm{~min}$ in the presence of an increasing concentration of ExoIII. When required, the nucleoprotein complex was dissociated by heating at $65{ }^{\circ} \mathrm{C}$ in the presence of $95 \%$ formamide and $25 \mathrm{mM}$ EDTA. Products were analysed on $1 \%$ agarose gels and DNA bands were visualized with ethidium bromide.

For determination of the affinity constant of DRA0282 for different DNA substrates, $200 \mathrm{ng}$ DNA was incubated with an increasing concentration of recombinant DRA0282 $(4 \mathrm{nM}$ to $1.42 \mu \mathrm{M})$ for $10 \mathrm{~min}$, and products were analysed on $0.8 \%$ agarose gels. Ethidium bromide-stained DNA fluorescence intensity was measured using ImageJ software (Abramoff et al., 2004). The integrated intensity for bound and unbound fractions per unit area was measured separately, and the fraction bound to the protein was plotted as a function of the protein concentration using GraphPad Prism 5. The $K_{\mathrm{d}}$ for curve fitting of individual plots was determined by the software, working on the principle of the least-squares method and applying the formula $Y=B_{\max } \times[\mathrm{X}] / K_{\mathrm{d}}+[\mathrm{X}]$, where $B_{\max }$ is the maximum binding capacity, $Y$ is the bound fraction and $[\mathrm{X}]$ is the protein concentration.

\section{RESULTS AND DISCUSSION}

\section{Identification of DRA0282 from a protein mixture exhibiting ATP-stimulated DNA protection}

Heparin-binding proteins purified from cells undergoing PIR show kinetically the appearance of nucleolytic activity (Kamble et al., 2010). The $1 \mathrm{~h}$ PIR proteins did not show any inherent nucleolytic activity, which, however, was expressed upon dephosphorylation with alkaline phosphatase. Alkaline phosphatase-treated $1 \mathrm{~h}$ PIR proteins were refractionated on a Mono-Q column (Fig. 1a). The fractions were checked for nuclease activity towards PCRamplified DNA with and without ATP. It was found that the nucleolytic activity was fractionated (Fig. 1b), and only fraction 12 showed ATP inhibition of nucleolytic function (Fig. 1c). Fractions 6, 7 and 8 showed strong DNA-binding activity. Other fractions, such as $9,10,13-18$ and 20 , showed neither nucleolytic activity nor an effect of ATP on the quality and quantity of the DNA substrate as compared with the control. This suggested that the nucleolytic function of fraction 12 was sensitive to ATP. This fraction was analysed by FTICR-MS, and matched a number of proteins represented by at least five or more peptides (Supplementary Table S2). These included some known proteins as well as a large number of uncharacterized ORFs, including DR_0129, DR_A0282, DR_1124, DR_1768, DR_2417 $\mathrm{m}$ and DR_2563. However, no proteins were annotated as nucleases or kinases in this fraction. Among these, the ORFs DR_0129, DR_1124, DR_1768, DR_2417 m and DR_2563 have also been found in a multiprotein DNAprocessing complex identified independently in the same bacterium that also exhibits an uncharacterized ATPsensitive exonucleolytic function (Kota \& Misra, 2008). Fraction 12 also contained DRA0282, a hypothetical protein, with the largest number of FTICR-MS peptides (84), which was characterized here for its in vitro activity and in vivo role, if any, in radiation resistance.

\section{DRA0282 shows structural similarities to Ku-type proteins}

Multiple sequence alignments of DRA0282 with human Ku 80 showed a close similarity to the $\beta$-barrel of the $\mathrm{Ku}$

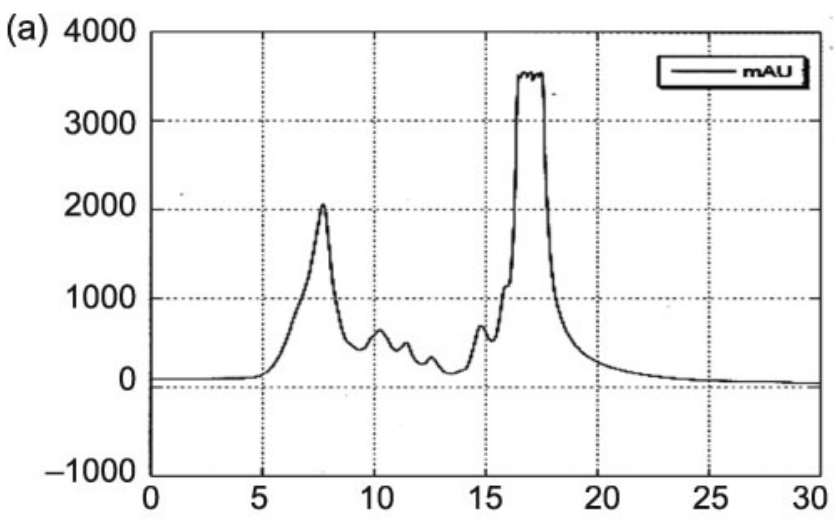

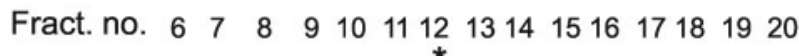
(b)

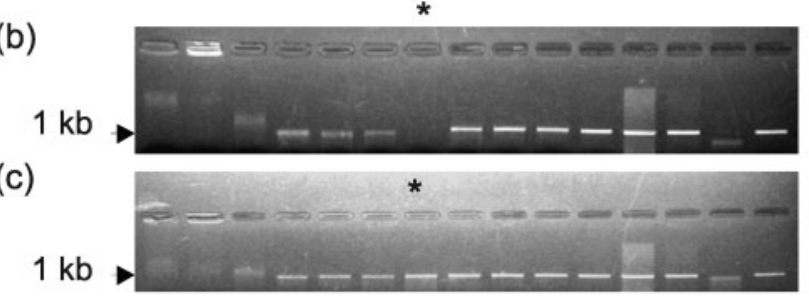

Fig. 1. Fractionation and nucleolytic activity assay of heparinbinding proteins from $D$. radiodurans. Heparin-binding proteins were isolated from cells allowed to recover for $1 \mathrm{~h}$ post-irradiation, and were fractionated on MonoO columns by FPLC (a). Nearly $500 \mathrm{ng}$ of proteins of each fraction was tested for nucleolytic activity with $100 \mathrm{ng}$ dsDNA substrate in buffer containing $5 \mathrm{mM}$ $\mathrm{MnCl}_{2}$, both in the absence (b) and the presence (c) of $2 \mathrm{mM} \mathrm{ATP}$ pre-incubated with the proteins for $20 \mathrm{~min}$. (b, c) Asterisks mark fraction 12, which contained the hypothetical protein DRA0282. 
core domain (Supplementary Fig. S1). Phylogenetic analysis showed DRA0282 clustering with eukaryotic $\mathrm{Ku}$ proteins (Supplementary Fig. S2). This was further verified by the alignment of DRA0282 with other Ku-like proteins from both prokaryotes and eukaryotes. Results showed that $\sim 150$ amino acid residues from the $\mathrm{N}$ terminus of DRA0282 were homologous to the $\mathrm{N}$ terminus of human and yeast $\mathrm{Ku} 80$. This forms the $\alpha / \beta$ domain, also known as the Rossman fold, which signifies the binding of nucleotides by this protein. Further, the 150 amino acid residues from 250-400 of DRA0282 showed the highest homology to the central domain known as the Ku core domain in $\mathrm{Ku}$ proteins, which is responsible for their binding to free DNA ends (Aravind \& Koonin, 2001). The secondary structure predicted by PyMOL showed extensive $\beta$-sheets at regular intervals, interspersed by coils. Although the DRA0282 sequence showed the overall $\alpha / \beta$ domain structure of $\mathrm{Ku} 80 \mathrm{~m}$, it lacked certain segments, such as $\alpha 2$ and $\beta 17$ (Supplementary Fig. S1 and Fig. 2). The overall similarities of this protein to $\mathrm{Ku}$-like proteins prompted us to build a 3D model using the human $\mathrm{Ku}$ heterodimer as template (Arnold et al., 2006). Regions with gaps had high root mean square deviation (RMSD), while regions with sequence overlap had a maximum RSMD of $4^{\circ}$, and the modal RMSD value was 0.8 . Unlike human $\mathrm{Ku}$, which is activated by ATP, DRA0282 was inhibited by it. This difference could be attributed to the absence of the $\alpha 2$ loop in DRA0282 and the resulting changes in its structure. The core domain of this protein resembled the Ku80 core domain. The $\alpha 7-\beta 18$ loop, which is responsible for dsDNA binding in Ku80, showed a significant match with DRA0282, while $\beta 10-\beta 13$ showed a poor structural alignment. The homology of DRA0282 to human Ku80 and its homologues was therefore through its $\mathrm{N}$ terminus, while its C-terminal domain was different. It could be speculated that this protein has evolved through genomic rearrangement under the pressure of natural selection. The results from online servers were intriguing. PHYRE returned a receptor-type tyrosine protein phosphatase as the best match [Protein Data Bank (PDB) ID: 2V5Y], while I-TASSER returned a sialidase from Micromonospora spp. (PDB ID: 1EUT), and FUGUE returned measles virus haemagglutinin (PDB ID: 2ZB6). These proteins have in common extensive $\beta$-sheet structures. These results indicated the structural resemblance of DRA0282 to Ku80 protein in having DNAbinding domains.

\section{DRA0282 is a DNA-binding protein with an ability to protect dsDNA in solution}

The purified recombinant DRA0282 protein (Supplementary Fig. S3) was incubated with ssDNA and linear dsDNA in the presence of different metal ions. The protein showed strong binding to both dsDNA and ssDNA in the presence of $\mathrm{Mn}^{2+}$, while this activity was not observed in the presence of $\mathrm{Ca}^{2+}$ and $\mathrm{Mg}^{2+}$ (Fig. 3a). DRA0282 showed stronger binding to ssDNA than to dsDNA in the presence of $\mathrm{Mn}^{2+}$ (Fig. 3b). It did not bind to dsDNA in the presence of $\mathrm{Zn}^{2+}$, while its binding to ssDNA in the presence of $\mathrm{Zn}^{2+}$ was minor compared with its binding in the presence of $\mathrm{Mn}^{2+}$. Recombinant DRA0282 showed strong binding to superhelical plasmid DNA, without affecting the topology or size of the plasmid DNA. This was confirmed by the complete recovery of the substrate in its original form upon heating with $95 \%$ formamide and $25 \mathrm{mM}$ EDTA at $65{ }^{\circ} \mathrm{C}$ (Fig. 3b), which breaks the nucleoprotein interaction in vitro (O'Donovan et al., 1994). This indicated that DRA0282 was a $\mathrm{Mn}^{2+}$-dependent

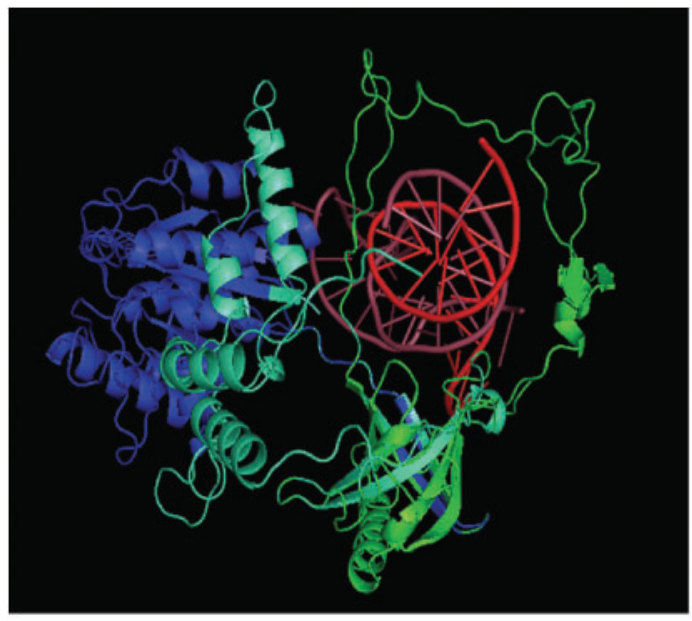

DRA0282

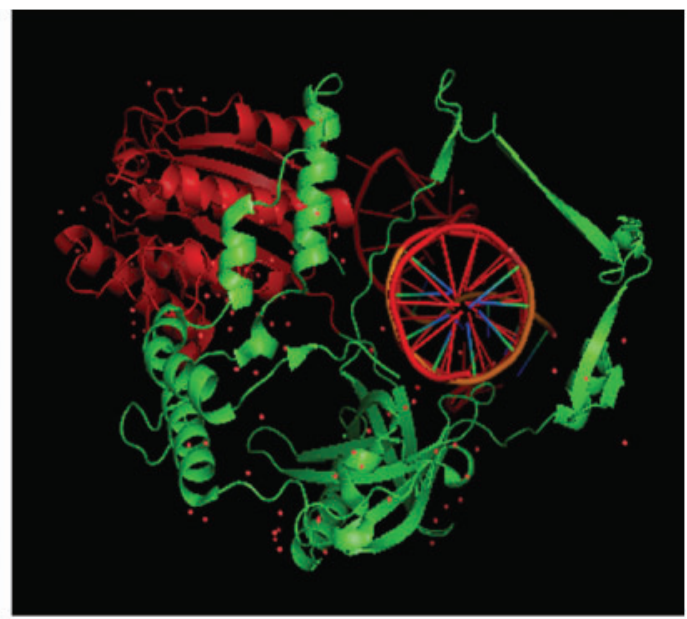

Human Ku80

Fig. 2. Structural similarities of DRA0282 and human Ku80. The 3D models of DRA0282 and human Ku80 were compared to find similarities in the dsDNA-binding motifs. The N-terminal Von Willebrand domain is coloured blue in DRA0282 and red in human Ku80, while the Ku core domain is coloured green in both molecules. 
(a)

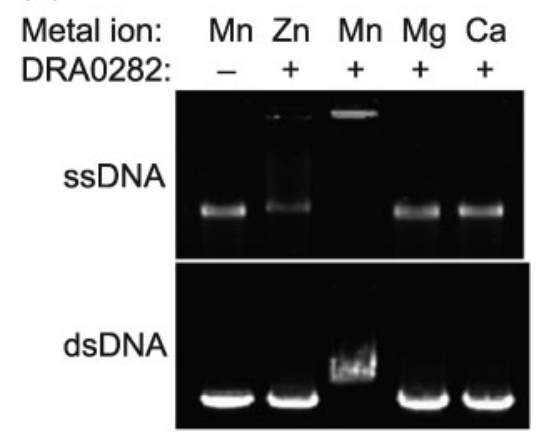

(c)

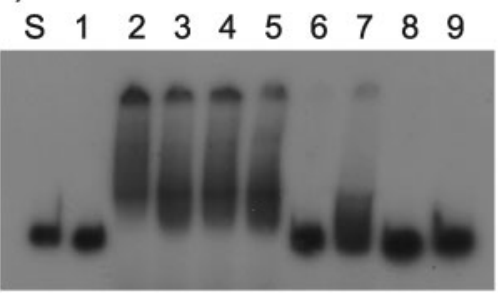

(b)

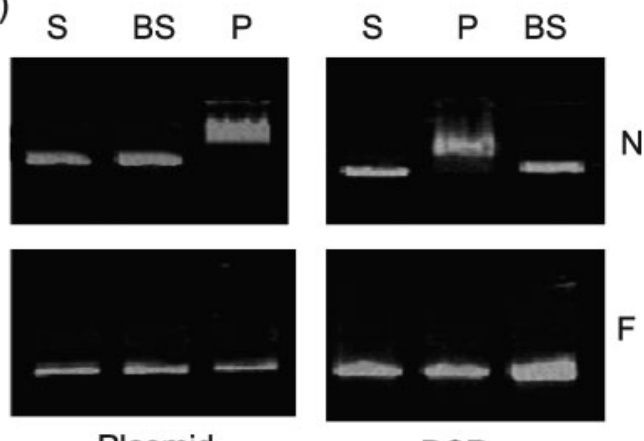

Plasmid

PCR

(d)

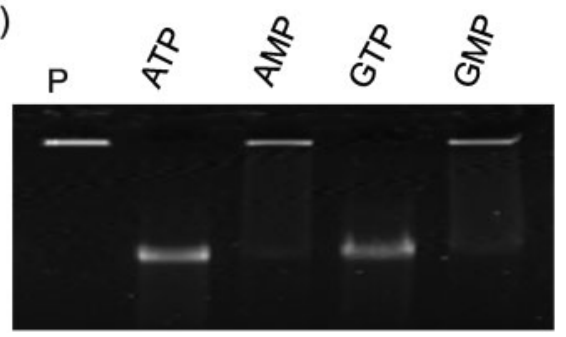

Fig. 3. Characterization of the DNA-binding activity of DRA0282. (a) One hundred nanograms of purified recombinant DRA0282 was incubated with $200 \mathrm{ng} \mathrm{M13mp18} \mathrm{ssDNA} \mathrm{and} 200 \mathrm{ng}$ dsDNA in buffer supplemented with $5 \mathrm{mM} \mathrm{ZnCl}_{2}, \mathrm{MnCl}_{2}$, $\mathrm{MgCl}_{2}$ or $\mathrm{CaCl}_{2}$, and products were analysed on $1 \%$ agarose. (b) DRA0282 (P) was incubated with both linear (PCR) and superhelical (plasmid) dsDNA (S), with BSA (BS) as a control. One set of reaction mixtures was treated with $95 \%$ formamide, $25 \mathrm{mM}$ EDTA $(\mathrm{F})$, while another set was kept as a control $(\mathrm{N})$, and both sets were analysed on $1 \%$ agarose gels. (c) Autoradiogram showing the 200 bp dsDNA labelled with ${ }^{32} \mathrm{P}$ at the $5^{\prime}$ end (lane S) incubated with either 100 ng BSA (lane 1) or $100 \mathrm{ng}$ DRA0282 (lanes 2-9). For the competition assay, the protein was pre-incubated separately with $50 \mathrm{ng} B \mathrm{BmHI}$ (lane 3 ), EcoRV- (lane 4) or Pstl-digested dsDNA (lane 5), M13mp18 ssDNA (lane 6) or supercoiled plasmid DNA (lane 7), before the addition of radiolabelled probe. DNA-binding activity (lane 2) was also checked in the absence (lane 8) and presence (lane 9) of $5 \mathrm{mM} \mathrm{Mn}^{2+}+2 \mathrm{mM}$ ATP. Products were separated by $6 \%$ native PAGE and dried, and the autoradiogram was developed. (d) The effect of $2 \mathrm{mM}$ ATP, AMP, GTP or GMP on the ssDNA-binding activity of DRA0282 was monitored on an agarose gel.

DNA-binding protein. The effects of the types of DNA ends and ssDNA on dsDNA binding were monitored by a competition assay. A $200 \mathrm{bp}{ }^{32} \mathrm{P}$-labelled dsDNA probe was used to study the binding preferences of DRA0282. dsDNA with different types of ends generated by BamHI, EcoRV or PstI did not disrupt the binding of DRA0282 to the probe, which, however, was readily disrupted by ssDNA (Fig. 3c). These activities were $\mathrm{Mn}^{2+}$-dependent and sensitive to ATP (Fig. 3c). Further, the purified protein showed the highest binding constant $\left(K_{\mathrm{d}}\right)$ of $2.93 \mathrm{nM}$ for superhelical plasmid, followed by $60.22 \mathrm{nM}$ for linear ssDNA and $196.9 \mathrm{nM}$ for linear dsDNA (Fig. 4).

Since this protein contains a Ku80-type DNA-binding pocket and nucleotide interaction domain, the effect of nucleoside phosphates on DNA binding and the protection of DNA ends from ExoIII degradation were examined. The DNA-DRA0282 interaction was inhibited by ATP and GTP, while AMP and GMP did not show any measurable effect on this activity (Fig. 3d). These results suggested that DRA0282 was a DNA-binding protein with a relatively higher affinity for superhelical DNA and linear ssDNA as compared with linear dsDNA. The inhibition of the DNAprotein interaction by nucleoside triphosphates and not by monophosphates suggested the involvement of terminal phosphates rather than the adenyl group in the inhibition of the DNA-binding activity of this protein. Similarly, recombinant DRA0282 protected linear dsDNA from ExoIII degradation, whereby as much as $50 \mathrm{U}$ nuclease could not degrade the dsDNA substrate completely after pre-incubation with DRA0282 (Fig. 5a). An increasing concentration of DRA0282 afforded an increase in protection of DNA when challenged with $10 \mathrm{U}$ ExoIII, which was able to degrade the dsDNA substrate completely in the absence of DRA0282 (Fig. 5b). Since DNA binding by DRA0282 was inhibited by ATP, the effect of ATP on the dsDNA protection of DRA0282 was examined. In the presence of ATP, DRA0282 failed to protect DNA from ExoIII degradation, and eventually more than $90 \%$ of the DNA was degraded, in spite of the presence of $72 \mathrm{nM}$ DRA0282 (Fig. 5c), which had shown complete DNA protection in an earlier assay (Fig. 5b). Since ATP alone showed no effect on ExoIII activity (Fig. 5c, lane 6), and the 


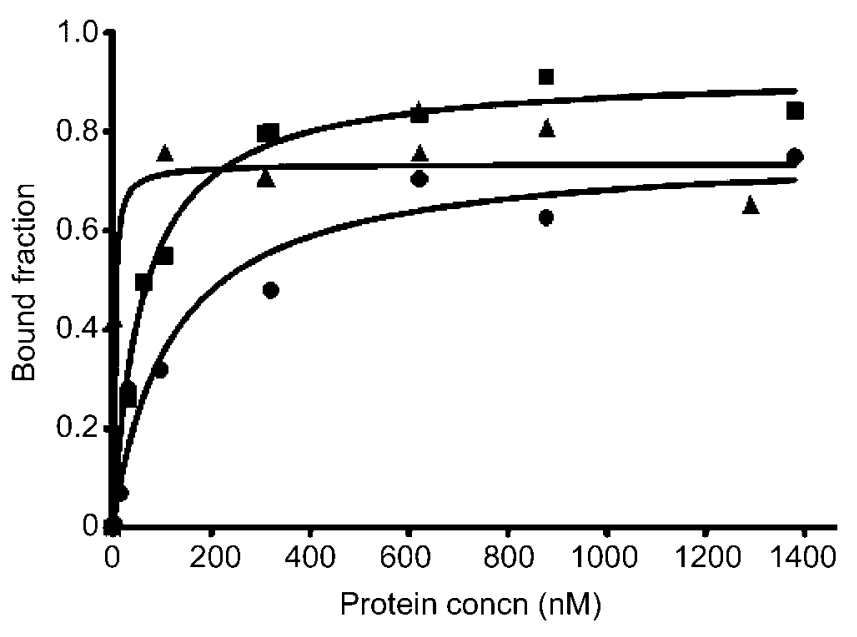

Fig. 4. Determination of the DNA-binding constant of DRA0282. Two hundred nanograms of linear dsDNA ( $)$, superhelical DNA $(\boldsymbol{\Delta})$ and linear ssDNA ( $\boldsymbol{\square})$ substrates were incubated with increasing concentrations of recombinant DRA0282 for $10 \mathrm{~min}$ at $37{ }^{\circ} \mathrm{C}$. Products were analysed on a $1 \%$ agarose gel. The DNA-protein bound fraction was plotted against protein concentration, and affinity constants of the protein for different DNA substrates were computed using GraphPad Prism 5 graphics, as described in Methods.

protection of dsDNA from the action of ExoIII was not seen in the presence of BSA as a control (Fig. $5 c$, lane 7 ), it is possible that the binding of ATP to DRA0282 prevents its binding to DNA, eventually leading to DNA degradation by ExoIII. These results suggest that DRA0282 is able to protect dsDNA from nucleolytic degradation by direct binding to the DNA substrate. Its higher affinity for superhelical DNA indicated a strong possibility of this protein interacting directly with the bacterial genome. The possibility that DRA0282 has a role in the DNA damage response of bacteria was further investigated by expressing this protein in E. coli and by generating a knockout of this gene in $D$. radiodurans.

\section{DRA0282 enhances the UVC and gamma radiation tolerance of $E$. coli}

The effect of DRA0282 on DNA damage tolerance was monitored in wild-type and mutant strains of E. coli (Supplementary Table S1). Wild-type cells expressing DRA0282 showed a nearly 10-fold higher tolerance to gamma radiation at a dose of $200 \mathrm{~Gy}$ (Fig. 6a), and a nearly three-log increase in UVC tolerance at a dose of $1.2 \mathrm{~kJ} \mathrm{~m}^{-2}$, as compared with untransformed cells (Fig. 6c). Interestingly, the recA mutant (JC1553) expressing DRA0282 did not show any increase in gamma radiation (Fig. 6b) and UVC tolerance (Fig. 6d). This indicated that DRA0282 functions in E. coli through RecA. Since RecA is involved in both homologous recombination and SOS response mechanisms in E. coli, the contribution of RecA in supporting DRA0282 function in (a)

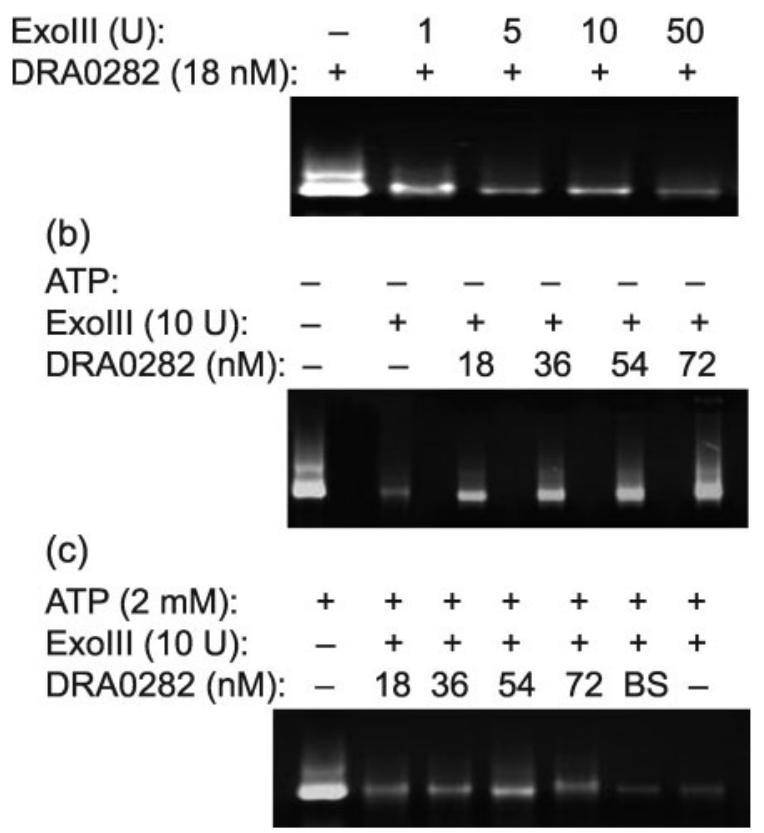

Fig. 5. DRA0282 protection of dsDNA from Exoll degradation. The $\sim 150 \mathrm{nM} 1 \mathrm{~kb}$ PCR-amplified dsDNA was pre-incubated with $\sim 18 \mathrm{nM}$ DRA0282 for 5 min before increasing concentrations of Exolll were added (a). Similarly, the DNA substrate was preincubated with increasing concentrations (18-72 nM) DRA0282 in the presence of $2 \mathrm{mM} \mathrm{MnCl}_{2}$ (b) and $2 \mathrm{mM}$ ATP along with $5 \mathrm{mM} \mathrm{Mn}^{2+}$ (c) before $10 \mathrm{U}$ Exolll was added. Reaction mixtures containing both BSA (BS) and Exolll, and Exolll alone, were used as controls. All reactions were carried out at $37{ }^{\circ} \mathrm{C}$ for $20 \mathrm{~min}$, and products were analysed on a $1 \%$ agarose gel.

E. coli via these pathways was examined. DRA0282 was expressed in E. coli strain DM49 (E. coli K-12, recA ${ }^{+}$lexA3) (Mount et al., 1972), and the effect of both UVC and gamma radiation was monitored. These cells showed an enhanced tolerance to both UV and gamma radiation (Fig. 7), albeit slightly lower than that observed in the wild-type background. The DM49 strain has a wild-type copy of RecA but a point mutation in the RecA co-protease cleavage site of LexA (lexA3), making it SOS-deficient but still recombinationproficient. These results suggested that DRA0282 plays an important role in the DNA damage tolerance of E. coli and works through mechanisms that involve RecA.

\section{DRA0282 deletion does not alter the pprA mutant phenotype in $D$. radiodurans}

The $\Delta d r A 0282$ mutant showed a dose-dependent response to gamma radiation-induced DNA damage. It showed nearly a 10-fold reduction with respect to wild-type tolerance at $14 \mathrm{kGy}$ gamma radiation (Fig. 8), while no difference in the gamma radiation response was noted in either a pprA single or a pprA:: cat $\Delta d r A 0282$ double mutant. Both these mutants showed a nearly two-log 

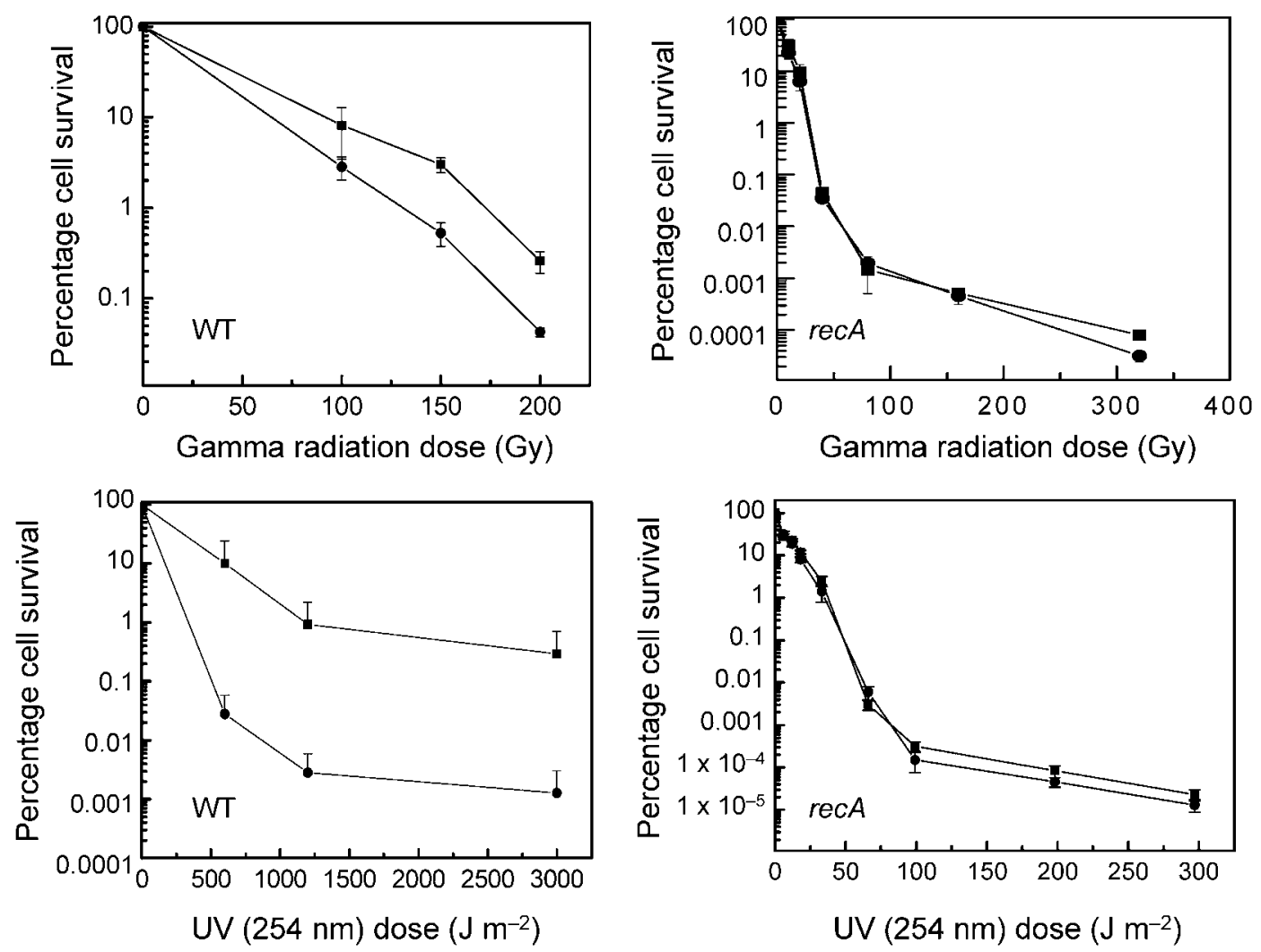

Fig. 6. Effect of DRA0282 overexpression on the DNA damage response of E. coli. E. coli AB1157 (wild-type; WT) and JC1553 (recA) cells expressing DRA0282 ( $\boldsymbol{\square})$ and corresponding controls ( $)$ were treated with different doses of gamma and UV $(254 \mathrm{~nm})$ radiation. c.f.u. were monitored after overnight incubation at $37{ }^{\circ} \mathrm{C}$. Cell survival of $100 \%$ corresponds to $5.423 \times 10^{7}$ and $3.124 \times 10^{7}$ cells $\mathrm{ml}^{-1}$ of the wild-type and recA mutant, respectively.

decrease with respect to the wild-type tolerance of gamma radiation (Fig. 8). This suggests that although both these proteins contribute to the radiation resistance of this bacterium, PprA plays the dominant role. The levels of expression of the $d r A 0282$ gene were increased nearly 20 fold within $1 \mathrm{~h}$ of post-irradiation growth (Supplementary Fig. S4), further supporting the possible involvement of DRA0282 in the radiation response of $D$. radiodurans.

Previously it has been reported that gamma-irradiated $D$. radiodurans $\mathrm{R} 1$ cells show rapid DNA degradation, which is arrested within 90 min of PIR (Khairnar et al., 2008; Slade et al., 2009). During this period the cells show a higher rate of DNA synthesis, leading to a net increase in DNA content and DSB repair. This period coincides with the expression of DNA-protecting proteins such as PprA (Narumi et al., 2004) and DdrA (Harris et al., 2004), and many uncharacterized ORFs, including DR_A0282 (Liu et al., 2003; Tanaka et al., 2004; Supplementary Fig. S4). The protection of linear dsDNA from ExoIII activity by PprA, DdrA and now the DRA0282 protein (Fig. 5), which is also found to have a role in radiation resistance of $D$. radiodurans (Fig. 8), suggested that DNA protection from nucleolytic degradation plays an important role in the radiation resistance of this bacterium. The fact that DRA0282 enhanced the UVC and gamma radiation resistance of wild-type E. coli and a lexA3 mutant, although to a lesser extent than the wild-type, while not doing so in a recA mutant, suggests a role for this protein in recombination-dependent mechanism(s) that contribute to DNA repair in E. coli. On the other hand, the molecular mechanisms that support the role of this protein in the radiation resistance of $D$. radiodurans are not yet clear. However, DRA0282 showed structural homology to $\mathrm{Ku}$ homologues, and the different roles of Ku-type proteins, including non-homologous end-joining (NHEJ) and DSB repair, have been shown in higher organisms (Downs \& Jackson, 2004). For example, human hPso4, a protein having similarity to DRA0282 (Supplementary Fig. S5), has been shown to bring Metnase, a human DSB repair protein with SET and transposase/nuclease domains (Lee et al., 2005), to the sites of DSB repair (Zhang et al., 2005; Lu \& Legerski, 2007; Beck et al., 2008). hPso4 is known to bind dsDNA non-specifically, and has pleiotropic functions in DNA recombination and error-prone repair. The hPso4 protein is induced 15- to 30-fold in cells exposed to gamma radiation and chemical mutagens, but not UV radiation (Mahajan \& Mitchell, 2003). These findings indicate the 

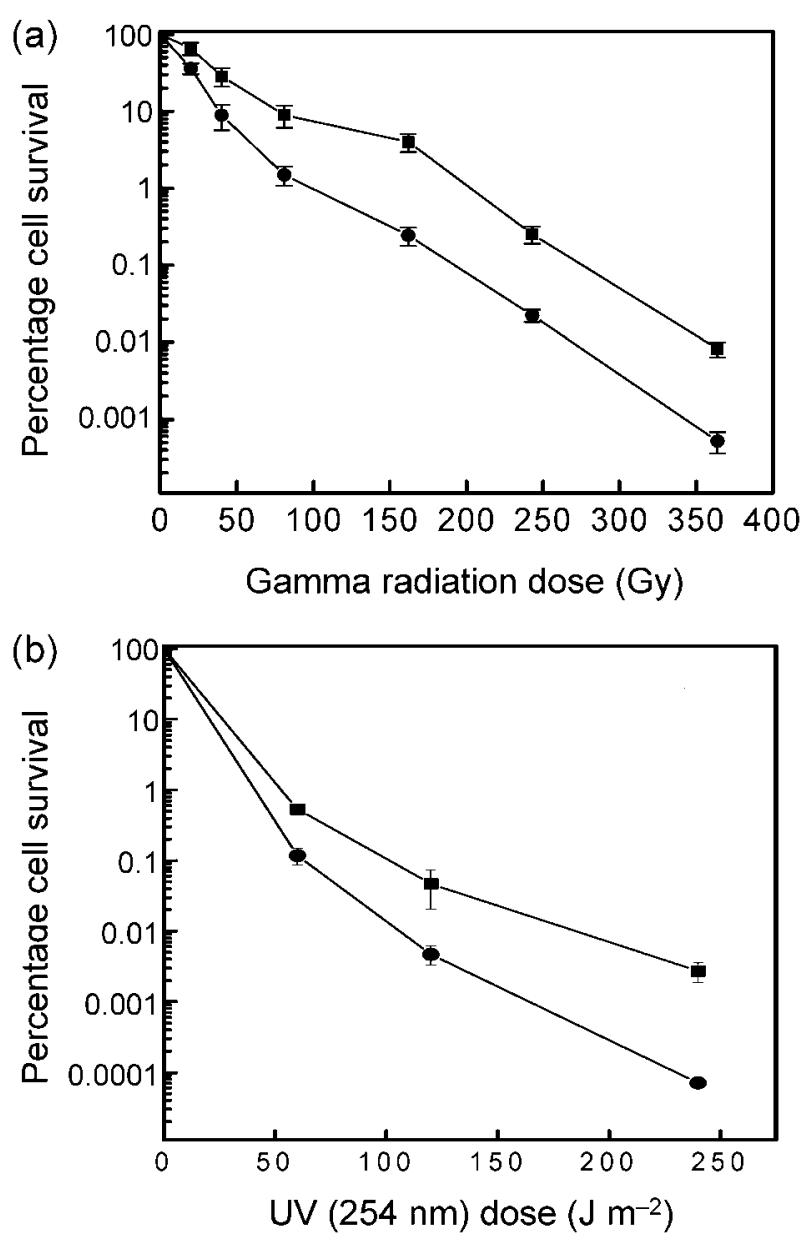

Fig. 7. Effect of DRA0282 on DNA damage tolerance of SOSdeficient and recombination-proficient E. coli. E. coli DM49 (lexA3 mutant) cells expressing DRA0282 (回) or harbouring the expression vector $(\bullet)$ were treated with different doses of gamma (a) and UV (254 $\mathrm{nm}$ ) (b) radiation, and cell survival was monitored at $37{ }^{\circ} \mathrm{C}$. Cell survival of $100 \%$ corresponds to $7.21 \times 10^{7}$ cells ml ${ }^{-1}$.

possible role of $\mathrm{Ku}$ homologues in DSB repair by both NHEJ and recombination functions. Although the existence of NHEJ-type activity has not been demonstrated in $D$. radiodurans, its genome encodes several other hypothetical proteins which could constitute an NHEJ pathway, and therefore the occurrence of such a mechanism cannot be ruled out in this bacterium. The existence of an NHEJtype mechanism has been reported in other bacteria, including Bacillus subtilis (Weller et al., 2002) and Mycobacterium (Gong et al., 2005; Pitcher et al., 2007). Recently, an alternative mechanism of DNA ends joining has been demonstrated in E. coli (Chayot et al., 2010). Although further studies will be required to understand the molecular mechanism underlying the roles of DRA0282 in the radioresistance of $D$. radiodurans, this study reports the characterization of the hypothetical protein DRA0282 as a DNA-binding protein with a higher affinity for superhelical DNA and with a role in dsDNA protection, as well as its

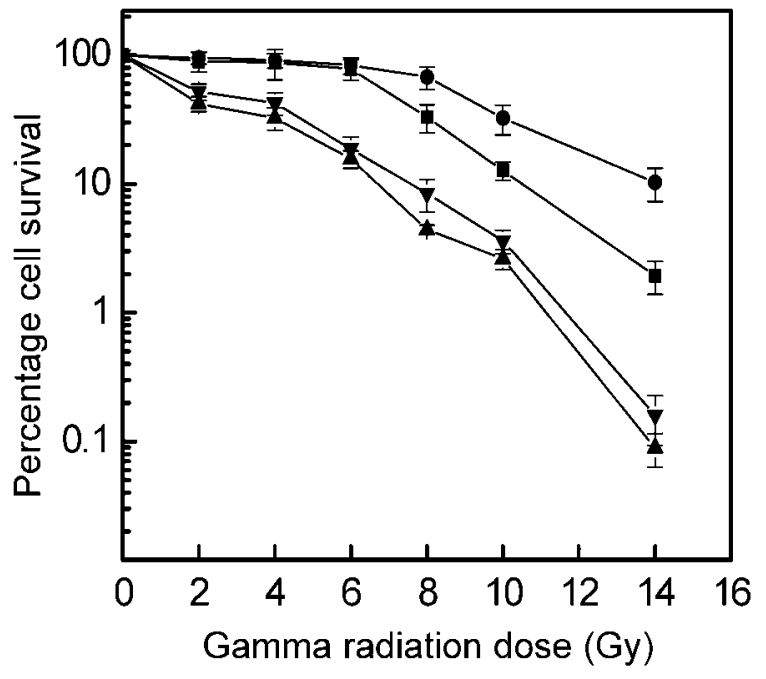

Fig. 8. Effect of $d r A 0282$ deletion on the gamma radiation tolerance of $D$. radiodurans. Cells of $D$. radiodurans R1 (wild-type; $\mathbf{0}$ ) and its $\Delta d r A 0282$ single mutant ( $\boldsymbol{\square}), p p r A:$ : cat $\Delta d r A 0282$ double mutant $(\boldsymbol{\nabla})$ and $p p r A$ : : cat single mutant $(\boldsymbol{\Lambda})$ were treated with different doses of gamma radiation, and cell survival was monitored. Cell survival of $100 \%$ corresponds to $1.45 \times 10^{7}, 4.12 \times 10^{6}, 2.54 \times 10^{7}$

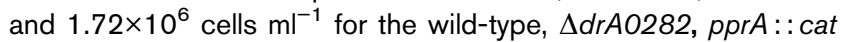
and $p p r A:$ : cat $\triangle d r A 0282$ strains, respectively.

contribution to bacterial resistance to DNA damage by a mechanism that requires a functional RecA, at least in E. coli.

\section{ACKNOWLEDGEMENTS}

The authors thank Dr S. K. Apte for his criticism and constructive comments during the preparation of the manuscript, Professor John R. Battista, Louisiana State University Baton Rouge, for providing laboratory space to H.S.M., and Professor Mary Lipton for proteome analysis. We gratefully acknowledge Dr Knut Ivan Kristiansen, Oslo University Hospital, Oslo, Norway, and Professor I. Narumi, Japan Atomic Energy Research Institute, Takasaki, Japan, for providing $E$. coli DM49 and the pprA mutant, respectively. H.S. M. thanks the Department of Biotechnology, Government of India, for an overseas senior research associateship.

\section{REFERENCES}

Abramoff, M. D., Magelhaes, P. J. \& Ram, S. J. (2004). Image processing with ImageJ. Biophoton Int 11, 36-42.

Aravind, L. \& Koonin, E. V. (2001). Prokaryotic homologs of the eukaryotic DNA-end-binding protein $\mathrm{Ku}$, novel domains in the $\mathrm{Ku}$ protein and prediction of a prokaryotic double-strand break repair system. Genome Res 11, 1365-1374.

Arnold, K., Bordoli, L., Kopp, J. \& Schwede, T. (2006). The SWISS-MODEL workspace: a web-based environment for protein structure homology modelling. Bioinformatics 22, 195-201.

Battista, J. R., Park, M. J. \& McLemore, A. E. (2001). Inactivation of two homologues of proteins presumed to be involved in the 
desiccation tolerance of plants sensitizes Deinococcus radiodurans $\mathrm{R} 1$ to desiccation. Cryobiology 43, 133-139.

Beck, B. D., Park, S. J., Lee, Y. J., Roman, Y., Hromas, R. A. \& Lee, S. H. (2008). Human Pso4 is a metnase (SETMAR)-binding partner that regulates metnase function in DNA repair. J Biol Chem 283, 9023-9030.

Bentchikou, E., Servant, P., Coste, G. \& Sommer, S. (2010). A major role of the RecFOR pathway in DNA double-strand-break repair through ESDSA in Deinococcus radiodurans. PLoS Genet 6, e1000774.

Blasius, M., Hübscher, U. \& Sommer, S. (2008). Deinococcus radiodurans: what belongs to the survival kit? Crit Rev Biochem $\mathrm{Mol}$ Biol 43, 221-238.

Chayot, R., Montagne, B., Mazel, D. \& Ricchetti, M. (2010). An endjoining repair mechanism in Escherichia coli. Proc Natl Acad Sci U S A 107, 2141-2146.

Clark, A. J. \& Margulies, A. D. (1965). Isolation and characterization of recombination deficient mutants of E. coli K12. Proc Natl Acad Sci U S A 53, 451-459.

Cox, M. M. \& Battista, J. R. (2005). Deinococcus radiodurans - the consummate survivor. Nat Rev Microbiol 3, 882-892.

Daly, M. J. \& Minton, K. W. (1996). An alternative pathway of recombination of chromosomal fragments precedes recA-dependent recombination in the radioresistant bacterium Deinococcus radiodurans. J Bacteriol 178, 4461-4471.

Daly, M. J., Ouyang, L., Fuchs, P. \& Minton, K. W. (1994). In vivo damage and recA-dependent repair of plasmid and chromosomal DNA in the radiation-resistant bacterium Deinococcus radiodurans. J Bacteriol 176, 3508-3517.

Daly, M. J., Gaidamakova, E. K., Matrosova, V. Y., Vasilenko, A., Zhai, M., Venkateswaran, A., Hess, M., Omelchenko, M. V., Kostandarithes, H. M. \& other authors (2004). Accumulation of $\mathrm{Mn}(\mathrm{II})$ in Deinococcus radiodurans facilitates gamma-radiation resistance. Science 306, 1025-1028.

Daly, M. J., Gaidamakova, E. K., Matrosova, V. Y., Vasilenko, A., Zhai, M., Leapman, R. D., Lai, B., Ravel, B., Li, S. M. \& other authors (2007). Protein oxidation implicated as the primary determinant of bacterial radioresistance. PLoS Biol 5, e92.

Downs, J. A. \& Jackson, S. P. (2004). A means to a DNA end: the many roles of Ku. Nat Rev Mol Cell Biol 5, 367-378.

Gong, C., Bongiorno, P., Martins, A., Stephanou, N. C., Zhu, H., Shuman, S. \& Glickman, M. S. (2005). Mechanism of nonhomologous end-joining in mycobacteria: a low-fidelity repair system driven by Ku, ligase D and ligase C. Nat Struct Mol Biol 12, 304-312.

Harris, D. R., Tanaka, M., Saveliev, S. V., Jolivet, E., Earl, A. M., Cox, M. M. \& Battista, J. R. (2004). Preserving genome integrity: the DdrA protein of Deinococcus radiodurans R1. PLoS Biol 2, e304.

Kamble, V. A., Rajpurohit, Y. S., Srivastava, A. K. \& Misra, H. S. (2010). Increased synthesis of signaling molecules coincides with reversible inhibition of nucleolytic activity during postirradiation recovery of Deinococcus radiodurans. FEMS Microbiol Lett 303, $18-25$.

Khairnar, N. P. \& Misra, H. S. (2009). DNA polymerase X from Deinococcus radiodurans implicated in bacterial tolerance to DNA damage is characterized as a short patch base excision repair polymerase. Microbiology 155, 3005-3014.

Khairnar, N. P., Kamble, V. A. \& Misra, H. S. (2008). RecBC enzyme overproduction affects UV and gamma radiation survival of Deinococcus radiodurans. DNA Repair (Amst) 7, 40-47.

Kota, S. \& Misra, H. S. (2006). PprA: a protein implicated in radioresistance of Deinococcus radiodurans stimulates catalase activity in Escherichia coli. Appl Microbiol Biotechnol 72, 790-796.
Kota, S. \& Misra, H. S. (2008). Identification of a DNA processing complex from Deinococcus radiodurans. Biochem Cell Biol 86, $448-458$.

Lee, S.-H., Oshige, M., Durant, S. T., Rasila, K. K., Williamson, E. A., Ramsey, H., Kwan, L., Nickoloff, J. A. \& Hromas, R. (2005). The SET domain protein Metnase mediates foreign DNA integration and links integration to nonhomologous end-joining repair. Proc Natl Acad Sci U S A 102, 18075-18080.

Liu, Y., Zhou, J., Omelchenko, M. V., Beliaev, A. S., Venkateswaran, A., Stair, J., Wu, L., Thompson, D. K., Xu, D. \& other authors (2003). Transcriptome dynamics of Deinococcus radiodurans recovering from ionizing radiation. Proc Natl Acad Sci U S A 100, 4191-4196.

Lu, X. \& Legerski, R. J. (2007). The Prp19/Pso4 core complex undergoes ubiquitylation and structural alterations in response to DNA damage. Biochem Biophys Res Commun 354, 968-974.

Mahajan, K. N. \& Mitchell, B. S. (2003). Role of human Pso4 in mammalian DNA repair and association with terminal deoxynucleotidyl transferase. Proc Natl Acad Sci U S A 100, 10746-10751.

Makarova, K. S., Aravind, L., Wolf, Y. I., Tatusov, R. L., Minton, K. W., Koonin, E. V. \& Daly, M. J. (2001). Genome of the extremely radiationresistant bacterium Deinococcus radiodurans viewed from the perspective of comparative genomics. Microbiol Mol Biol Rev 65, 44-79.

Markillie, L. M., Varnum, S. M., Hradecky, P. \& Wong, K. K. (1999). Targeted mutagenesis by duplication insertion in the radioresistant bacterium Deinococcus radiodurans: radiation sensitivities of catalase $($ katA) and superoxide dismutase $(\operatorname{sodA})$ mutants. J Bacteriol 181, 666-669.

Minton, K. W. (1994). DNA repair in the extremely radioresistant bacterium Deinococcus radiodurans. Mol Microbiol 13, 9-15.

Misra, H. S., Pandey, P. K., Modak, M. J., Vinayak, R. \& Pandey, V. N. (1998). Polyamide nucleic acid-DNA chimera lacking the phosphate backbone are novel primers for polymerase reaction catalyzed by DNA polymerases. Biochemistry 37, 1917-1925.

Misra, H. S., Khairnar, N. P., Kota, S., Shrivastava, S., Joshi, V. P. \& Apte, S. K. (2006). An exonuclease I-sensitive DNA repair pathway in Deinococcus radiodurans: a major determinant of radiation resistance. Mol Microbiol 59, 1308-1316.

Montague, M., Barnes, C., Smith, H. O., Chuang, R. Y. \& Vashee, S. (2009). The evolution of RecD outside of the RecBCD complex. J Mol Evol 69, 360-371.

Mount, D. W., Low, K. B. \& Edmiston, S. J. (1972). Dominant mutations (lex) in Escherichia coli K-12 which affect radiation sensitivity and frequency of ultraviolet light-induced mutations. J Bacteriol 112, 886-893.

Narumi, I., Satoh, K., Cui, S., Funayama, T., Kitayama, S. \& Watanabe, H. (2004). PprA: a novel protein from Deinococcus radiodurans that stimulates DNA ligation. Mol Microbiol 54, 278-285.

O'Donovan, A., Scherly, D., Clarkson, S. G. \& Wood, R. D. (1994). Isolation of active recombinant XPG protein, a human DNA repair endonuclease. J Biol Chem 269, 15965-15968.

Pitcher, R. S., Brissett, N. C. \& Doherty, A. J. (2007). Nonhomologous end-joining in bacteria: a microbial perspective. Annu Rev Microbiol 61, 259-282.

Rajpurohit, Y. S., Gopalakrishnan, R. \& Misra, H. S. (2008). Involvement of a protein kinase activity inducer in DNA double strand break repair and radioresistance of Deinococcus radiodurans. J Bacteriol 190, 3948-3954.

Sambrook, J. \& Russell, D. W. (2001). Molecular Cloning: a Laboratory Manual, 3rd edn. Cold Spring Harbor, NY: Cold Spring Harbor Laboratory. 
Schäfer, M., Schmitz, C., Facius, R., Horneck, G., Milow, B., Funken, K. H. \& Ortner, J. (2000). Systematic study of parameters influencing the action of Rose Bengal with visible light on bacterial cells: comparison between the biological effect and singlet-oxygen production. Photochem Photobiol 71, 514-523.

Slade, D., Lindner, A. B., Paul, G. \& Radman, M. (2009). Recombination and replication in DNA repair of heavily irradiated Deinococcus radiodurans. Cell 136, 1044-1055.

Tanaka, M., Earl, A. M., Howell, H. A., Park, M. J., Eisen, J. A., Peterson, S. N. \& Battista, J. R. (2004). Analysis of Deinococcus radiodurans's transcriptional response to ionizing radiation and desiccation reveals novel proteins that contribute to extreme radioresistance. Genetics $\mathbf{1 6 8}$, 21-33.

Wang, J., Li, T., Guo, X. \& Lu, Z. (2005). Exonuclease III protection assay with FRET probe for detecting DNA-binding proteins. Nucleic Acids Res 33, e23.
Weller, G. R., Kysela, B., Roy, R., Tonkin, L. M., Scanlan, E., Della, M., Devine, S. K., Day, J. P., Wilkinson, A. \& other authors (2002). Identification of a DNA nonhomologous end-joining complex in bacteria. Science 297, 1686-1689.

White, O., Eisen, J. A., Heidelberg, J. F., Hickey, E. K., Peterson, J. D., Dodson, R. J., Haft, D. H., Gwinn, M. L., Nelson, W. C. \& other authors (1999). Genome sequence of the radioresistant bacterium Deinococcus radiodurans $\mathrm{R} 1$. Science 286, 1571-1577.

Zahradka, K., Slade, D., Bailone, A., Sommer, S., Averbeck, D., Petranovic, M., Lindner, A. B. \& Radman, M. (2006). Reassembly of shattered chromosomes in Deinococcus radiodurans. Nature 443, 569-573.

Zhang, N., Kaur, R., Lu, X., Shen, X., Li, L. \& Legerski, R. J. (2005). The Pso4 mRNA splicing and DNA repair complex interacts with WRN for processing of DNA interstrand cross-links. J Biol Chem 280, 40559-40567.

Edited by: T. Msadek 